\title{
Growth, behavior, and economics of group-fed dairy calves fed once or twice daily in an organic production system
}

\author{
M. J. Kienitz, B. J. Heins, ${ }^{1}$ and H. Chester-Jones \\ Department of Animal Science, University of Minnesota, St. Paul 55108
}

\begin{abstract}
Heifer calves $(\mathrm{n}=102)$ were used to evaluate the effect of once- or twice-daily feeding on growth, behavior, and economics of calves in an organic group management system. Calves were assigned to replicate feeding groups of 10 in superhutches by birth order, during 2 seasons from September to December 2013 and March to May 2014 at the University of Minnesota West Central Research and Outreach Center, Morris. Calves in groups were the experimental unit. Breed groups of calves were Holsteins $(\mathrm{n}=26)$, crossbreds $(\mathrm{n}=45)$ including combinations Holsteins, Montbéliarde, and Viking Red (selected for high production), and crossbreds $(\mathrm{n}=31)$ including combinations of Holsteins, Jersey, Normande, and Viking Red (selected for robustness). Treatment groups were once-daily feeding $(1 \times)$ or twice-daily feeding $(2 \times)$. Calves in both groups were fed $6 \mathrm{~L}$ per calf/daily of organic milk with $13 \%$ total solids and then weaned at $60 \mathrm{~d}$ when the group consumption averaged $0.91 \mathrm{~kg} / \mathrm{d}$ of starter per calf. Body weight and hip height were recorded at birth, once a week, at weaning, and at 90 and $120 \mathrm{~d}$ of age. Hobo Pendant G loggers (Onset Computer Corp., Bourne, MA) were applied to the right rear leg of calves to measure total lying and standing time. Data were analyzed using PROC MIXED of SAS (SAS Institute Inc., Cary, NC). Independent variables for analyses were the fixed effects of birth weight (co-variable), season of birth, and treatment group, along with replicate as a random effect. No significant differences were found between feeding groups for body weight, weight gain, average daily gain, hip height, or heart girth. For calves in $1 \times$ and $2 \times$ groups, respectively, weaning group performance was as follows: gain per day was 0.79 and 0.81 $\mathrm{kg}$, weaning weight was 92.7 and $93.3 \mathrm{~kg}$, and weaning hip height was 95.2 and $95.3 \mathrm{~cm}$. Daily gain to $90 \mathrm{~d}$ was 0.85 and $0.85 \mathrm{~kg}$, and daily gain to $120 \mathrm{~d}$ was 0.85
\end{abstract}

Received August 18, 2016.

Accepted December 10, 2016.

${ }^{1}$ Corresponding author: hein0106@umn.edu and $0.83 \mathrm{~kg}$ for $1 \times$ and $2 \times$ calves, respectively. For lying time, calves in groups $1 \times(988 \mathrm{~min} / \mathrm{d})$ and $2 \times$ $(995 \mathrm{~min} / \mathrm{d})$ did not differ. During the evening hours, $2 \times$ calves had lesser lying times $(34 \mathrm{~min} / \mathrm{h}$ for $1 \times ; 28$ $\mathrm{min} / \mathrm{h}$ for $2 \times$ ) because they were fed at $1800 \mathrm{~h}$ every evening. The average cost per kilogram of gain for the $2 \times(\$ 4.03 / \mathrm{kg})$ calves was greater than that for the $1 \times$ $(\$ 3.56 / \mathrm{kg})$ calves. In summary, group-fed calves fed once a day in an organic production system had similar average daily gains and body dimensions compared with calves fed twice a day. Our results indicated that there is no need for twice-daily milk feeding under the conditions of the present study.

Key words: group housing, organic dairy, profitability

\section{INTRODUCTION}

Organic dairy production has gained more attention because of increased demand for organic products, which in turn has offered farmers a higher milk premium for organic milk. Organic dairy production accounts for the second largest category in organic food production and produces $\$ 5.5$ billion a year in sales in the United States, with milk sales leading organic commodities at $\$ 1.1$ billion in sales (USDA, 2016a). This growth in organic dairy has slowed economic losses of smaller dairy operations in the Upper Midwest. In the United States, the number of certified-organic dairy cows increased $271 \%$ from 2002 to 2008 , and totaled 228,116 in 2014 (USDA, 2016a).

Dairy heifers are an important and expensive aspect of dairy farming and starting these heifers on a balanced diet is critical to their future efficiency, productivity, and longevity (Soberon et al., 2012). After feed costs, replacement heifers represent the second largest expense on a dairy farm and, with increased production, the need for replacements has increased (Akins et al., 2015). The cost of raising these heifers depends on the amount of nonsalable or saleable milk fed to calves. The US National Organic Program states that organic dairy farms are required to feed only whole milk to dairy calves (UDSA, 2016b) and this milk can be either nonsalable or saleable. 
Group housing of dairy calves is gaining in popularity with producers over individually housed calves. Group housing has been shown to have many benefits, including reduced labor and bedding costs and improved gain (Costa et al., 2016). For organic dairy farms in the United States, many farms are exploring the benefits of group housing of calves (Bjorklund et al., 2013). Along with group housing, an increasing number of organic dairy producers are feeding calves once daily or exploring this practice because of high labor costs or a reduced labor force on smaller organic dairy farms.

Galton and Brakel (1976) reported that calves fed once daily did not differ in ADG or rumen development compared with calves fed twice daily. Furthermore, those authors reported a significant increase in labor hours and cost of calves fed twice daily (Galton and Brakel, 1976). Hopkins (1997) found that calves fed once daily were able to achieve acceptable growth by 6 mo of age. Additionally, Gleeson et al. (2007) reported that group-fed calves could be fed once per day and have adequate gains with reduced labor.

There remain many questions in regards to costs, performance, and behavior of calves fed once daily, especially in group-housed calves in an organic production system. The cost effectiveness of feeding calves once daily and productivity of calves take precedence for organic farmers because, with a healthy start to life, their calves will become productive grazing animals in the future. Therefore, the objective of this study was to investigate the effect of feeding frequency on growth, profitability, and behavior of group-fed dairy calves in an organic dairy production system. We hypothesized that calves fed once versus twice daily would have similar growth rates and reduced costs to $90 \mathrm{~d}$ of age, as well as similar behavior compared with calves fed twice daily.

\section{MATERIALS AND METHODS}

\section{Experimental Design and Collection of Data}

This study was conducted at the University of Minnesota West Central Research and Outreach Center (WCROC; Morris, MN), and all the animal procedures involving animal care and management were approved by the University of Minnesota Institutional Animal Care and Use Committee (\#1305-30661A). The research dairy at WCROC is a 250-head low-input and organic grazing system. The research herd has applied a crossbreeding approach since 2000, and details are described in Heins et al. (2010); the 1964 Holstein control population design is described in Hansen (2000). Data were collected for 102 organic dairy heifer
Table 1. Distribution of organic dairy calves by breed group and feeding group

\begin{tabular}{lcc}
\hline Breed group $^{1}$ & $\begin{array}{c}\text { Once-daily } \\
\text { feeding }\end{array}$ & $\begin{array}{c}\text { Twice-daily } \\
\text { feeding }\end{array}$ \\
\hline Holstein & 13 & 13 \\
HMS & 22 & 23 \\
HJS & 17 & 14 \\
Total calves & 52 & 50 \\
\hline
\end{tabular}

${ }^{1}$ HMS $=$ crossbreds of Holstein, Montbéliarde, and Viking Red; HJS = crossbreds of Holstein, Jersey, Normande, and Viking Red.

calves born in 2 calving seasons: 35 heifer calves were born from September 18 to November 30, 2013, and 67 heifer calves were born from March 24 to May 31, 2014. Breed groups of calves were Holsteins $(\mathrm{n}=26)$, including both 1964 genetics and contemporary genetics; crossbreds $(\mathrm{n}=45)$ including combinations of Holstein, Montbéliarde, and Viking Red; and crossbreds $(\mathrm{n}=31)$ including combinations of Jersey, Viking Red, and Normande. The distribution of calves by breed group and feeding group is presented in Table 1. The Viking Red breed was formed by combining the genetic improvement programs for the Swedish Red, Finnish Ayrshire, and Danish Red breeds, which have historically shared ancestry and similar selection criteria with emphasis on the fertility, survival, and health of cows.

Calves were separated from their dams at birth, moved to indoor housing in individual pens, and fed 1.9 L (2 quarts) of colostrum per $41 \mathrm{~kg}$ of BW twice daily for $3 \mathrm{~d}$. Healthy calves that showed aggressive suckling ability were moved to groups in superhutches by d 4 after the morning feeding. For this study, all calves were healthy and moved to group housing. The superhutches used for group housing had an indoor area $(3.66 \times 6.10$ $\mathrm{m})$ bedded with organic wheat straw and access to an outdoor area that measured $3.66 \times 6.10 \mathrm{~m}\left(7.32 \mathrm{~m}^{2}\right.$ per calf inside and outside area). Twenty-four hours after birth, a single blood sample was taken via jugular venipuncture and collected in 10-mL serum Vacutainer tubes (Becton Dickinson and Co., Franklin Lakes, NJ). Samples were centrifuged at $1,800 \times g$ for 20 min to separate the serum and immediately analyzed for total serum protein using a digital refractometer (Misco digital dairy refractometer, model PA203X, Misco, Cleveland, OH; Deelen et al., 2014).

Heifer calves were randomly allocated to 1 of 2 replicated feeding groups of 10 calves per superhutch based on birth order. A group of 10 calves was formed before the next group of 10 calves was formed. The time for group formation ranged from 7 to $19 \mathrm{~d}$ in fall 2013 and from 5 to $15 \mathrm{~d}$ in spring 2014 . For the $1 \times$ calf groups, 1 group during the fall of 2013 had 5 calves and 1 group during the spring of 2014 had 7 calves. Most calves are 
born during the spring-calving season at the WCROC dairy, and only 35 heifer calves were born during the fall of 2013 and those calves contributed meaningful information for treatment group comparisons. Calves that were fed $1 \times$ were fed $6 \mathrm{~L}$ of organic milk per calf per day at $0800 \mathrm{~h}$, and those fed $2 \times$ were fed 2 feedings of $3 \mathrm{~L}$ of organic milk at 0800 and $1800 \mathrm{~h}$. Calves were fed $6 \mathrm{~L}$ of milk because the WCROC generates an ample supply of waste milk due to the seasonality of calving in the herd. Jasper and Weary (2002) reported that the more milk calves are fed, the greater their weight gain. Therefore, WCROC has chosen to feed more milk because of labor and economic conditions, although only $22 \%$ of dairy farms in the United States (USDA, 2016c) feed $6 \mathrm{~L}$ or more to dairy calves before weaning. The organic milk was $13 \%$ total solids (unpasteurized whole organic milk from the bulk tank or from high-SCC cows), averaging $4.2 \%$ fat, $3.3 \%$ protein, and $5.5 \%$ other solids. Calves were weaned when the youngest calf in the group reached $60 \mathrm{~d}$ of age and when the group of 10 calves consumed an average of $0.91 \mathrm{~kg}$ (airdry) of calf starter per calf daily for 4 consecutive days. Heifer calves were fed with a 10-calf Skellerup peach teat feeder with 61-L liquid volume capacity (Skellerup Industries, Christchurch, New Zealand), and it was disinfected daily after each feeding. Texturized calf starter was provided free choice, starting when calves were moved to the superhutches and was 19\% CP from corn, wheat, soybean meal, soybean oil, and minerals. The calf starter was mixed onsite at WCROC and contained (as a percentage of DM) $89.9 \%$ DM, $19.4 \%$ CP, $19.2 \%$ NDF, $5.94 \%$ crude fat, $5.9 \%$ ash, $1.52 \%$ calcium, $0.74 \%$ phosphorus, $50.2 \%$ NFC, $47.1 \%$ starch, and $0.13 \mathrm{MJ}$ of $\mathrm{ME} / \mathrm{kg}$. Calves also received free-choice water from d 3 and organic hay starting at $7 \mathrm{wk}$.

Group-housed calves were weighed using a digital scale once a week after the a.m. feeding $(0800 \mathrm{~h})$ to measure individual milk intake. Body measurements, including birth weight, weaning weight, weaning hip height, weaning heart girth, total gain, ADG, 90-d weight, and 120-d weight, were recorded for each individual calf. Mortality record and health treatments were documented on an individual calf basis. Liquid milk and calf starter that was consumed and refused at each daily feeding was recorded for the pen as a group.

Once calves were weaned, they were moved to longterm group pens but remained in their specific replicate treatment groups until $120 \mathrm{~d}$ of age. The long-term group pens housed 20 to 30 calves based on BW, and at 5 mo of age all heifer calves were moved together. When heifer calves reached 6 mo of age, they were moved out to pasture and were supplemented with a TMR during the nongrazing season.

\section{Lying Behavior}

A total of 48 focal animals $(251 \times$ calves and $232 \times$ calves) were used to evaluate superhutch lying behavior. Lying time, lying bouts, and lying-bout duration were measured using Hobo Pendant G data loggers (Onset Computer Corp., Bourne, MA). Data loggers were attached to 5 calves per replicate superhutch to collect lying behavior at 60-s intervals (Bonk et al., 2013) and placed on the right hind leg of the calf at $3 \mathrm{~d}$ of age after entrance into the superhutch. The loggers were wrapped in a piece of SyrFlex (SyrVet Inc., Waukee, IA) cohesive bandage to provide cushion and attached to the lateral side of the leg using SyrFlex bandage. Data loggers were kept on the calf through weaning; each logger was attached for $15 \mathrm{~d}$ and removed, data were downloaded, and the logger reattached until the calf was weaned. The data were downloaded with Onset Hoboware software and exported to Excel (Microsoft Corp., Redmond, WA). Daily lying times, frequency of lying bouts, and lying-bout duration were computed for each calf using a macro in SAS (SAS Institute Inc., Cary, NC) developed by N. Chapinal (University of British Columbia, Vancouver, BC, Canada).

\section{Profitability}

Total feed cost was estimated as a function of the total cost for organic milk and organic calf starter for feeding frequency groups to weaning and to the first 90 d of age. The default milk price was $\$ 0.675 / \mathrm{kg}$, which was the mean organic mailbox milk price from 2013 to 2014 for the WCROC organic dairy. The average organic grain starter mix was $\$ 0.617 / \mathrm{kg}$. Labor was valued a $\$ 15 / \mathrm{h}$, which was the hourly rate paid to student labor to feed the calves at the WCROC dairy. Total feed cost was the sum of milk intake and starter intake for a group of dairy calves. Average cost per kilogram of gain was the total cost divided by the total sum of weight gain for a group of dairy calves. Treatment costs were the actual costs of administering treatments to calves. The profitability analysis was calculated for the preweaning period and for the first $90 \mathrm{~d}$ of life for a group of 10 calves.

\section{Statistical Analysis}

For statistical analysis of birth weight, total serum protein, weaning weight, days on milk, total gain, ADG, hip height at weaning, heart girth at weaning, 90-d weight, and 120-d weight, independent variables were fixed effects of season of birth and feeding group ( $1 \times$ or $2 \times$ ), with superhutch as a random replicate effect. 
Furthermore, birth weight was included as a covariate in the statistical model. For statistical analysis of milk intake, starter intake, milk price, total feed costs, total gain from birth to weaning, total gain from birth to 90 $\mathrm{d}$ of age, and cost per kilogram of gain, independent variables were fixed effects of season of birth and feeding group, along with super hutch as a random effect. All observations within pens were averaged for analyses because pen was the experimental unit. Preliminary analysis for all traits indicated that interactions of season and feeding group were not significant $(P>0.05)$, so the interaction effects were removed from the model.

For analysis of lying behavior (daily lying time, number of lying bouts per day, and lying-bout duration), independent variables were fixed effects of season of birth and feeding group $(1 \times$ or $2 \times)$, with superhutch and calf nested within superhutch as a random replicate effect. The interaction of time of day and treatment was also included in the statistical model. The compound symmetry covariance structure was used because it resulted in the lowest Akaike information criterion for repeated measures (Littell et al., 1998.) A repeated statement included day and calf nested within superhutch as the subject. Pen was used as the experimental unit for all statistical analysis. For all measurements, the MIXED procedure (SAS Institute, 2014) was used to obtain solutions and conduct the ANOVA. All treatment results were reported as least squares means with significance declared at $P<0.05$.

\section{RESULTS AND DISCUSSION}

\section{Body Measurements}

Results for preweaning and early postweaning body measurements across feeding groups for the organic heifer calves are given in Table 2. Serum total protein of the calves was similar for the $1 \times$ and $2 \times$ calves and greater than the recommended amount of $5.2 \mathrm{~g} / \mathrm{dL}$ (Godden, 2008) that indicates adequate passive transfer of calves. Birth weight, weaning weight, 90-d weight, and $120-\mathrm{d}$ weight were not different for the $1 \times$ and $2 \times$ calves. This is consistent with what was found in a previous study by Galton and Brakel (1976), which showed similar growth characteristics (birth weight and ADG) between calves fed once or twice daily. Additionally, Stanley et al. (2002) found that feeding milk replacer once versus twice daily to dairy calves had no adverse effects on weight gain. Weaning hip height $(95.2 \mathrm{~cm}$ for $1 \times$ and $95.3 \mathrm{~cm}$ for $2 \times$ ) and weaning heart girth $(107.0 \mathrm{~cm}$ for $1 \times$ and $107.9 \mathrm{~cm}$ for $2 \times)$ were not different between feeding groups. Furthermore, the ADG to weaning of the $1 \times$ calves was similar to that of the $2 \times$ calves ( 0.79 vs. $0.81 \mathrm{~kg} / \mathrm{d}$ ), and ADG was similar at 90 and $120 \mathrm{~d}$ for the $1 \times$ and $2 \times$ calves. Previously, Stanley et al. (2002) found that feeding milk replacer once versus twice daily to dairy calves had no adverse effects on weight gain. In another study that evaluated calves fed once or twice daily, Kehoe et al. (2007) found that calves did not differ in growth measurements whether they were fed once or twice daily. The calves in the current study were fed $6 \mathrm{~L}$ of waste milk, which is greater than the amount fed on the average dairy farm in the United States - most US farms feed 4 to 5 L daily to calves (USDA, 2016c). Perhaps the greater growth of calves in this study was achieved because calves were fed a high milk allowance. The preweaning calves in the current study might have had lower growth rates if they had been fed $<6 \mathrm{~L} / \mathrm{d}$ of milk. Recently, Rosenberger et al. (2017) reported that calves fed higher milk allowance ( $>6$ L) had greater weight gains. Previous studies have reported that calves fed higher amounts of milk have decreased starter intake (Jasper and Weary, 2002; Gelsinger et al., 2016). However, starter intake in the current study did not appear to be decreased because of the greater milk allowance. Calves in this study were fed a greater milk allowance to achieve greater gains; however, both treatment groups were fed the same amount of milk and growth differences were not observed between groups because calves were fed the same total amount per day. To maximize profit, groupfed calves in an organic production system should be fed $>5 \mathrm{~L}$ of milk and weaned at 8 wk of age (Bjorklund et al., 2013).

Doubling a calf's birth weight by $60 \mathrm{~d}$ of age has become an industry standard for Holstein calves (DCHA, 2012). However, in the current study, only 85 to $96 \%$ of calves doubled their birth weight during the first $60 \mathrm{~d}$ of life, and this did not differ $(P>0.05)$ between feeding groups. Although some calves did not double their birth weight in $60 \mathrm{~d}$, all calves at $60 \mathrm{~d}$ were at least 1.5 times greater in BW than their birth weight, and some calves had tripled their birth weight. Van Amburgh et al. (2008) suggested that calves should double their birth weight by weaning to achieve higher future milk production; however, doubling calf birth weight by $60 \mathrm{~d}$ of age in this study may not be achievable for all calves due to the differences in genetic composition of the calves. Furthermore, individual animal variation within breed group may have contributed to calves not doubling their birth weight by $60 \mathrm{~d}$ of age. The range of unadjusted ADG for Holstein (0.55 to $0.97 \mathrm{~kg} / \mathrm{d}$ ), Holstein $\times$ Montbéliarde $\times$ Viking Red (0.40 to 1.07 $\mathrm{kg} / \mathrm{d})$, and Holstein $\times$ Jersey $\times$ Normande $\times$ Viking Red $(0.50$ to $0.98 \mathrm{~kg} / \mathrm{d})$ calves indicates individual animal variation. 
Table 2. Least squares means and standard errors of means for preweaning and early postweaning body measurements of group-fed organic dairy calves by feeding group ${ }^{1}$

\begin{tabular}{|c|c|c|c|c|}
\hline \multirow[b]{2}{*}{ Measurement } & \multicolumn{2}{|c|}{$\begin{array}{l}\text { Once-daily feeding } \\
\quad(\mathrm{n}=52)\end{array}$} & \multicolumn{2}{|c|}{$\begin{array}{l}\text { Twice-daily feeding } \\
\quad(\mathrm{n}=50)\end{array}$} \\
\hline & Mean & SEM & Mean & SEM \\
\hline Birth weight $(\mathrm{kg})$ & 37.0 & 0.9 & 37.5 & 0.9 \\
\hline Total serum protein $(\mathrm{g} / \mathrm{dL})$ & 6.4 & 0.1 & 6.6 & 0.2 \\
\hline Time on milk (d) & 68.5 & 1.9 & 67.6 & 1.9 \\
\hline Weaning weight $(\mathrm{kg})$ & 92.7 & 1.6 & 93.3 & 1.7 \\
\hline Weaning hip height $(\mathrm{cm})$ & 95.2 & 0.6 & 95.3 & 0.6 \\
\hline Weaning heart girth $(\mathrm{cm})$ & 107.0 & 0.8 & 107.9 & 0.8 \\
\hline Total gain (birth to weaning) $(\mathrm{kg})$ & 54.7 & 1.8 & 55.3 & 1.7 \\
\hline $\mathrm{ADG}(\mathrm{kg} / \mathrm{d})$ & 0.79 & 0.01 & 0.81 & 0.01 \\
\hline Double weight by $60 \mathrm{~d}(\%)$ & 84.9 & 4.5 & 95.9 & 4.6 \\
\hline 90-d weight $(\mathrm{kg})$ & 123.5 & 2.4 & 121.2 & 2.5 \\
\hline 90-d hip height $(\mathrm{cm})$ & 99.9 & 0.6 & 100.0 & 0.7 \\
\hline $90-\mathrm{d}$ heart girth $(\mathrm{cm})$ & 119.6 & 5.2 & 120.1 & 5.1 \\
\hline ADG birth to $90 \mathrm{~d}(\mathrm{~kg} / \mathrm{d})$ & 0.85 & 0.2 & 0.85 & 0.2 \\
\hline 120 -d weight $(\mathrm{kg})$ & 145.4 & 3.1 & 139.5 & 3.1 \\
\hline 120-d hip height $(\mathrm{cm})$ & 104.3 & 0.9 & 103.4 & 0.9 \\
\hline 120 -d heart girth $(\mathrm{cm})$ & 123.2 & 1.4 & 122.8 & 1.6 \\
\hline ADG birth to $120 \mathrm{~d}(\mathrm{~kg} / \mathrm{d})$ & 0.85 & 0.02 & 0.83 & 0.02 \\
\hline
\end{tabular}

${ }^{1}$ Reported means and SEM are based on group averages rather than individual calves. There were no significant difference between feeding groups for all variables.

\section{Profitability}

Least squares means for milk intake, starter intake, and economic analysis of milk and starter for a group of 10 calves for feeding groups during the preweaning period and to $90 \mathrm{~d}$ of age are summarized in Table 3 . The reported means and standard errors of the means are based on an individual calf with analysis done on a group average of 10 calves, and results divided by 10 to be expressed on an individual basis. Feeding groups of calves differed $(P<0.05)$ from each other only for labor cost and average cost per gain. As expected, the $1 \times$ calves had lower $(P<0.05)$ labor cost during the preweaning period than the $2 \times$ calves. Most dairy calves in the United States are fed at least twice daily (USDA, 2010); however, once-daily milk feeding of calves may reduce labor costs. Similarly, Galton and Brakel (1976) reported that feeding calves once daily required about $40 \%$ less labor than feeding calves twice daily. The average cost per kilogram of gain was greater $(P<0.05)$ for the $2 \times$ calves than for the $1 \times$ calves, being $\$ 4.03 / \mathrm{kg}$ and $\$ 3.56 / \mathrm{kg}$, respectively. For the current study, cost per kilogram of gain was 2.6 to 3.5 times greater than that reported by Raeth-Knight et al. (2009) for calves raised in Minnesota, because the price of organic milk and organic starter had a substantial effect on the cost of production. The cost of labor is often cited as the major reason why organic dairy producers

Table 3. Least squares means and standard errors of means for milk intake, starter intake, and economic analysis of milk and starter for feeding groups during the first $90 \mathrm{~d}$ of life ${ }^{1}$

\begin{tabular}{lccccc}
\hline & \multicolumn{2}{c}{ Once-daily feeding } & & \multicolumn{2}{c}{ Twice-daily feeding } \\
\cline { 2 - 3 } \cline { 5 - 6 } Measurement & Mean & SEM & & Mean & SEM \\
\hline Milk cost $(\$)$ & 255.0 & 4.8 & & 265.9 & 3.9 \\
Starter intake to weaning $(\mathrm{kg})$ & 66.5 & 6.4 & & 78.5 & 5.5 \\
Starter intake to 90 d $(\mathrm{kg})$ & 107.3 & 3.4 & & 103.9 & 2.8 \\
Starter cost $(\$)$ & 66.2 & 2.1 & & 64.1 & 1.7 \\
Total gain, birth to 90 d $(\mathrm{kg})$ & 83.7 & 8.4 & & 84.3 & 8.4 \\
Average total feed cost $(\$)$ & 320.2 & 5.9 & & 330.4 & 4.7 \\
Health cost $(\$)$ & 0.02 & 0.1 & & 0.14 & 0.1 \\
Labor cost $(\$)$ & $24.5^{\mathrm{a}}$ & 0.9 & & $50.8^{\mathrm{b}}$ & 0.7 \\
Average cost/gain $(\$ / \mathrm{kg})$ & $3.56^{\mathrm{a}}$ & 0.1 & & $4.03^{\mathrm{b}}$ & 0.1 \\
\hline
\end{tabular}

a,b Means within a row without common superscripts are different at $P<0.05$.

${ }^{1}$ Reported means and SEM are based on an individual calf with analysis done on a group average of 10 calves. Results were divided by 10 to be expressed on an individual basis. 
Table 4. Least squares means and standard errors of means for behavior measurements of individual group-fed organic dairy calves by feeding group ${ }^{1}$

\begin{tabular}{lccccc}
\hline & \multicolumn{2}{c}{$\begin{array}{c}\text { Once-daily feeding } \\
(\mathrm{n}=25)\end{array}$} & & \multicolumn{2}{c}{$\begin{array}{c}\text { Twice-daily feeding } \\
(\mathrm{n}=23)\end{array}$} \\
\cline { 2 - 3 } \cline { 5 - 6 } Measurement & Mean & SEM & & Mean & SEM \\
\hline Lying time $(\mathrm{min} / \mathrm{d})$ & 988 & 1.2 & & 995 & 1.0 \\
Standing time $(\mathrm{min} / \mathrm{d})$ & 452 & 1.2 & & 445 & 1.1 \\
Lying time on the left side of calf $(\mathrm{min} / \mathrm{d})$ & 487 & 1.8 & & 491 & 1.4 \\
Lying time on the right side of calf $(\mathrm{min} / \mathrm{d})$ & 500 & 0.9 & & 501 & 0.7 \\
\hline
\end{tabular}

${ }^{1}$ No significant difference between feeding groups for all variables.

have switched to feeding $1 \times$ in group-fed calves. In this experimental herd of calves, the average time to feed a group of 10 calves was about $12 \mathrm{~min}$, which corresponds to 1.2 min per calf.

\section{Lying Behavior}

The results for behavior measurements of individual calves by feeding group are given in Table 4. Calves born in the autumn were not different from calves born in the spring for lying time (990 vs. $993 \mathrm{~min} / \mathrm{d}$, respectively). We detected no difference in lying time for $1 \times$ calves $(988 \mathrm{~min} / \mathrm{d})$ compared with $2 \times$ calves (995 min/d). Furthermore, standing time did not differ between $1 \times$ and $2 \times$ heifer calves (452 vs. $445 \mathrm{~min} / \mathrm{d}$ ), respectively. This is consistent with past research with
Hobo loggers that reported calves stand an average of 350 to $550 \mathrm{~min} / \mathrm{d}$ (Bonk et al., 2013; Hill et al., 2013).

Lying time by feeding groups by hour during the day is reported in Figure 1. We observed a sharp decrease in lying time for both feeding groups at $0800 \mathrm{~h}$, which corresponded to the time of feeding in the morning. The $1 \times$ calves had lower lying time at 0900, 1000, 1100, $1300,1400,1500$, and $1600 \mathrm{~h}$ compared with the $2 \times$ calves. However, the $2 \times$ calves had lower lying time at $1700,1800,1900$, and $2100 \mathrm{~h}$ compared with the $1 \times$ calves. The results are consistent with feeding times during the day, because the $2 \times$ calves received half of the milk portion per feeding compared with the $1 \times$ calves. The $1 \times$ calves had greater lying time in the early evening, perhaps because they were resting for the night, whereas the $2 \times$ calves were preparing for

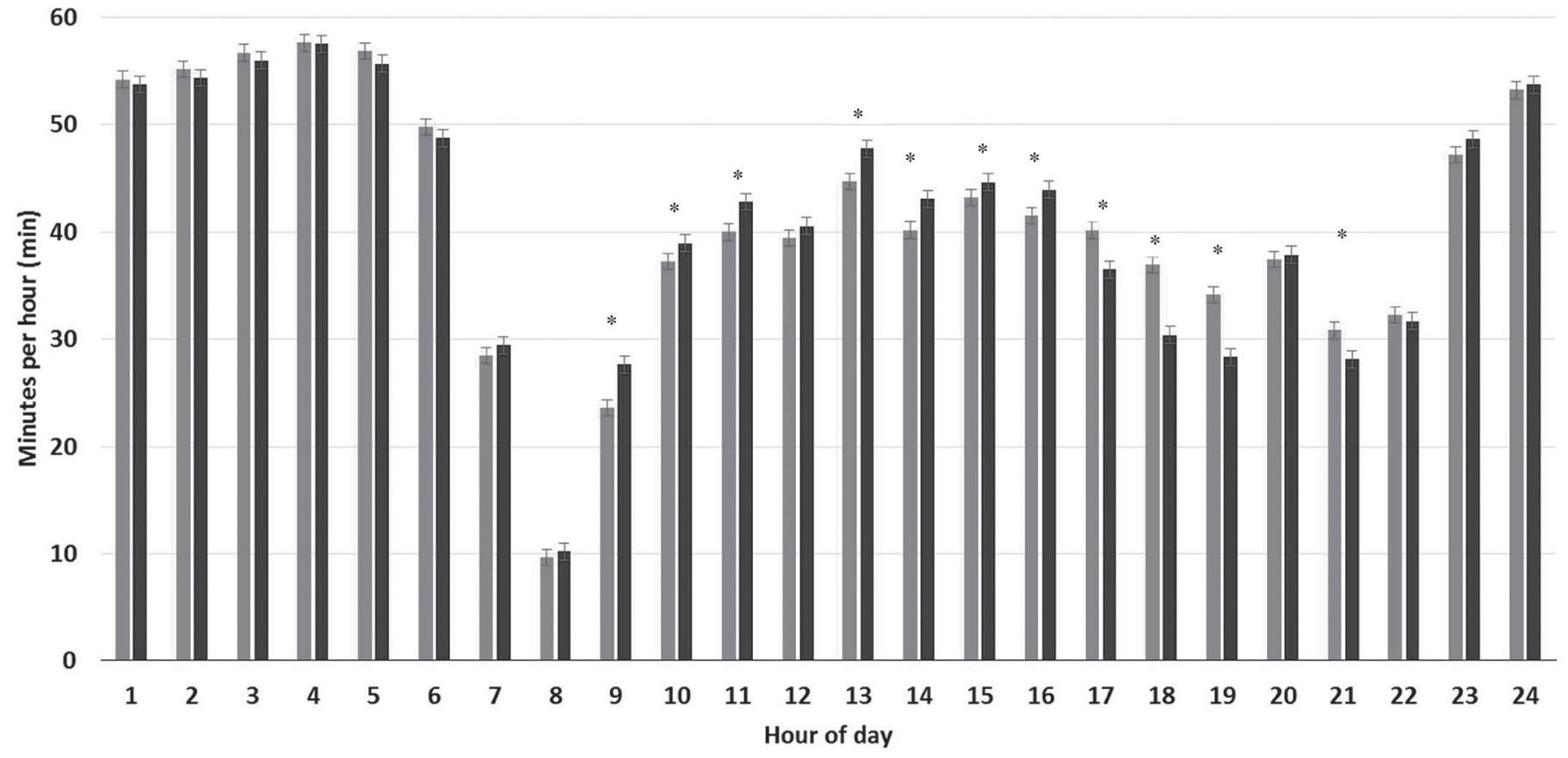

Figure 1. Least squares means for lying time by hour of day for group-fed organic calves fed once (gray) versus twice (black) per day. ${ }^{*}$ Means within an hour of day for feeding groups are different at $P<0.05$. Error bars indicate SEM. 
their second meal of the day. These results might indicate that calf activity during the day is correlated with feeding times. Numerous factors (eating grain, expressing group socialization behavior, wanting more milk) may explain why the $1 \times$ calves had shorter lying times after the morning feeding.

Future research with these organic dairy calves should explore the effect of feeding frequency of organic dairy calves with heifer growth, fertility, and first and subsequent lactation performance. Results of research will provide guidance to organic dairy producers for methods of feeding organic dairy calves for specific management systems. Irrespective of feeding system, successful management of dairy calves is critically important to an organic dairy. Organic dairy producers must focus on all aspects of dairy calf management to maintain growth rates and minimize health problems to ensure future profitability for the dairy farm.

\section{CONCLUSIONS}

Calves fed once daily had similar weight gains and body dimensions to calves fed twice daily. For the first $90 \mathrm{~d}$ of life, cost per kilogram of gain was lower for $1 \times$ calves than for $2 \times$ calves. Lying and standing time were directly affected by feeding time, and calves fed twice daily had significantly higher standing time in the evening hours during their second feeding. Based on the results of this study, organic dairy producers can achieve adequate BW gain with reduced labor in group-fed dairy calves fed once daily.

\section{ACKNOWLEDGMENTS}

The authors express gratitude to Darian Huot and coworkers at the West Central Research and Outreach Center for their assistance in data collection and care of animals. This work was supported by the USDA National Institute of Food and Agriculture (Washington, DC; Hatch Multistate NC-2042 Project Number MIN05-034; Project Accession Number 1000495).

\section{REFERENCES}

Akins, M. S., L. M. Vanderwerff, M. A. Hagedorn, P. C. Hoffman, S. L. Gunderson, and T. L. Kohlman. 2015. Economic costs and labor efficiencies associated with raising dairy herd replacements on Wisconsin dairy farms and custom heifer raising operations. Research Report. University of Wisconsin Dept. of Dairy Science, UW Extension and Cooperative Extension, Madison, WI. Accessed Aug. 17, 2016. http://fyi.uwex.edu/heifermgmt/rearing-costs/

Bjorklund, E. A., B. J. Heins, and H. Chester-Jones. 2013. Whole-milk feeding duration, calf growth, and profitability of group-fed calves in an organic production system. J. Dairy Sci. 96:7363-7370. https://doi.org/10.3168/jds.2013-6772.
Bonk, S., O. Burfeind, V. Suthar, and W. Heuwieser. 2013. Technical note: Evaluation of data loggers for measuring lying behavior in dairy calves. J. Dairy Sci. 96:3265-3271. https://doi.org/10.3168/ jds.2012-6003.

Costa, J. H. C., M. A. G. von Keyserlingk, and D. M. Weary. 2016. Invited review: Effects of group housing of dairy calves on behavior, cognition, performance, and health. J. Dairy Sci. 99:2453-2467. https://doi.org/10.3168/jds.2015-10144.

DCHA (Dairy Calf and Heifer Association). 2012. Gold Standards I. Production and performance standards established for Holstein calves, from birth to 6 months of age, across the United States. Accessed: Aug17, 2016. http://calfandheifer.org/gold_standards/ index.php.

Deelen, S. M., T. L. Ollivett, D. M. Haines, and K. E. Leslie. 2014. Evaluation of a Brix refractometer to estimate serum immunoglobulin G concentration in neonatal dairy calves. J. Dairy Sci. 97:3838-3844. https://doi.org/10.3168/jds.2014-7939.

Galton, D. M., and W. J. Brakel. 1976. Influence of feeding milk replacer once versus twice daily on growth, organ measurements, and mineral content of tissues. J. Dairy Sci. 59:944-948. https:// doi.org/10.3168/jds.S0022-0302(76)84302-0.

Gelsinger, S. L., A. J. Heinrichs, and C. M. Jones. 2016. A metaanalysis of the effects of preweaned calf nutrition and growth on first-lactation performance1. J. Dairy Sci. 99:6206-6214. https:// doi.org/10.3168/jds.2015-10744.

Gleeson, D. E., B. O'Brien, and R. J. Fallon. 2007. Feeding of cold whole milk once daily to calves in a group and its effect on calf performance, health, and labour input. Int. J. Appl. Res. Vet. Med. 5:97-104.

Godden, S. 2008. Colostrum management for dairy calves. Vet. Clin. North Am. Food Anim. Pract. 24:19-39. https://doi.org/10.1016/j. cvfa.2007.10.005.

Hansen, L. B. 2000. Consequences of selection for milk yield from a geneticist's viewpoint. J. Dairy Sci. 83:1145-1150. https://doi. org/10.3168/jds.S0022-0302(00)74980-0.

Heins, B. J., L. B. Hansen, A. R. Hazel, A. J. Seykora, D. G. Johnson, and J. G. Linn. 2010. Birth traits of pure Holstein calves versus Montbéliarde-sired crossbred calves. J. Dairy Sci. 93:2293-2299. https://doi.org/10.3168/jds.2009-2911.

Hill, T. M., H. Bateman, J. Aldrich, J. Quigley, and R. Schlotterbeck. 2013. Short communication: Intensive measurements of standing time of dairy calves housed in individual pens within a naturally ventilated, unheated nursery over different periods of the year. J. Dairy Sci. 96:1811-1814. https://doi.org/10.3168/jds.2012-6206.

Hopkins, B. A. 1997. Effects of the method of calf starter delivery and effects of weaning age on starter intake and growth of Holstein calves fed milk once daily. J. Dairy Sci. 80:2200-2203. https://doi. org/10.3168/jds.S0022-0302(97)76168-X.

Jasper, J., and D. M. Weary. 2002. Effects of ad libitum milk intake on dairy calves. J. Dairy Sci. 85:3054-3058. https://doi.org/10.3168/ jds.S0022-0302(02)74391-9.

Kehoe, S. I., C. D. Dechow, and A. J. Heinrichs. 2007. Effects of weaning age and milk feeding frequency on dairy calf growth, health and rumen parameters. Livest. Sci. 110:267-272. https://doi. org/10.1016/j.livsci.2006.11.007.

Littell, R. C., P. R. Henry, and C. B. Ammerman. 1998. Statistical analysis of repeated measures data using SAS procedures. J. Anim. Sci. 76:1216-1231.

Raeth-Knight, M., H. Chester-Jones, S. Hayes, J. Linn, R. Larson, D. Ziegler, B. Ziegler, and N. Broadwater. 2009. Impact of conventional or intensive milk replacer programs on Holstein heifer performance through six months of age and during first lactation. J. Dairy Sci. 92:799-809. https://doi.org/10.3168/jds.2008-1470.

Rosenberger, K., J. H. C. Costa, H. W. Neave, M. A. G. von Keyserlingk, and D. M. Weary. 2017. The effect of milk allowance on behavior and weight gains in dairy calves. J. Dairy Sci. 100:504-512. https://doi.org/10.3168/jds.2016-11195.

SAS Institute. 2014. SAS/STAT Software, Release 9.4. SAS Inst. Inc., Cary, NC.

Soberon, F., E. Raffrenato, R. W. Everett, and M. E. Van Amburgh. 2012. Preweaning milk replacer intake and effects on long-term 
productivity of dairy calves. J. Dairy Sci. 95:783-793. https://doi. org/10.3168/jds.2011-4391.

Stanley, C. C., C. C. Williams, B. F. Jenny, J. M. Fernandez, H. G. Bateman, W. A. Nipper, J. C. Lovejoy, D. T. Gantt, and G. E. Goodier. 2002. Effects of feeding milk replacer once versus twice daily on glucose metabolism in Holstein and Jersey calves. J. Dairy Sci. 85:2335-2343. https://doi.org/10.3168/jds.S00220302(02)74313-0.

USDA. 2010. Heifer Calf Health and Management Practices on U.S. Dairy Operations, 2007. \#550.0110. USDA:APHIS:VS CEAH, Fort Collins, CO.

USDA. 2016a. 2014 Organic Survey. National Agriculture Statistics Service. April 2016. Accessed Aug. 17, 2016. https://www.agcensus. usda.gov/Publications/2012/Online_Resources/Organics/.
USDA. 2016b. National Organic Program. United States Department of Agriculture, Agricultural Marketing Service. Accessed Aug. 17 2016. https://www.ams.usda.gov/about-ams/programs-offices/ national-organic-program.

USDA. 2016c. Dairy 2014: Dairy Cattle Management Practices in the United States, 2014. NAHMS \#692.0216. USDA-Animal and Plant Health Inspection Service (APHIS)-Veterinary Services (VS)-Center for Epidemiology and Health (CEAH), Fort Collins, CO.

Van Amburgh, M. E., F. Soberon, J. Karzses, and R. W. Everett. 2008. Early life nutrition and management impacts long-term productivity of calves. Pages 1-8 in Proc. 23rd Annual Southwest Nutrition and Management Conference, Tucson, Arizona. Department of Animal Sciences, University of Arizona, Tucson. 